\title{
Urea Cycle Disorders in Neonates: Six Case Reports
}

\section{Yenidoğanlarda Üre Döngüsü Bozukluğu: Altı Olgu Sunumu}

\author{
Kıymet Çelik¹, Demet Terek², Özgür Olukman¹, Mehtap Kağnıcı ${ }^{4}$, Şükran Keskin Gözmen³, \\ Erkin Serdaroğlư ${ }^{3}$, Şebnem Çalkavur ${ }^{1}$, Sertaç Arslanoğlu ${ }^{5}$ \\ ${ }^{1}$ Dr. Behçet Uz Children Disease and Surgery Training and Research Hospital, Clinic of Neonatology, Izmir, Turkey \\ ${ }^{2}$ Ege University Faculty of Medicine, Department of Pediatrics, Division of Neonatology, Izmir, Turkey \\ ${ }^{3}$ Dr. Behçet Uz Children Disease and Surgery Training and Research Hospital, Clinic of Pediatric Nephrology, Izmir, Turkey \\ ${ }^{4}$ Dr. Behçet Uz Children Disease and Surgery Training and Research Hospital, Clinic of Pediatric Metabolism, Izmir, Turkey \\ ${ }^{5}$ Istanbul Medeniyet University Faculty of Medicine, Department of Pediatrics, Division of Neonatology, Istanbul, Turkey
}

\begin{abstract}
Urea cycle disorders are a group of diseases associated with hyperammonemia, which causes severe neurological sequelae, seizures and psychomotor retardation. In this study, six newborn cases diagnosed between 2010-2014 as citrullinemia Type I (four cases) and argininosuccinic aciduria (two cases) are presented in terms of clinical course and treatment responses. Keywords: Newborn, urea cycle disorder, peritoneal dialysis
\end{abstract}

\section{ÖZ}

Üre döngüsü bozukluğu hiperamonyemi ile seyreden ve ciddi nörolojik sekeller, nöbetler, psikomotor retardasyona neden olabilen bir grup hastalıktır. Bu çalışmada 2010-2014 yıllarında yenidoğan döneminde tanı alan dördü sitrülinemi Tip I, ikisi argininosüksinik asidüri olmak üzere altı üre döngü bozukluğu olgusunun klinik seyri ve tedavi yanıtları sunulmuştur.

Anahtar Kelimeler: Yenidoğan, üre döngüsü bozukluğu, periton diyalizi

\section{Introduction}

The urea cycle is a metabolic pathway that allows the ammonia to turn into a product so as to remove it from the body. Enzyme deficiencies and transport defects on this pathway lead to hyperuricemia-induced urea cycle disorders (UCD). These enzymes are carbamoyl phosphate synthetase 1 (CPS1), ornithine transcarbamylase (OTC), argininosuccinate synthetase (ASS), argininosuccinate lyase (ASL), arginase and $\mathrm{N}$-acetylglutamate synthetase. Mitochondrial ornithine transporter 1 and aspartate/ glutamate transporter deficiency is also responsible for UCD (1). Except for the OTC defect due to the X-linked transition; UCD, an autosomal recessive familial disorder, is seen in 30.000 live births. In the newborn period,
UCD presents by different clinical tables ranging from severe disease to very mild findings in childhood and adulthood $(2,3)$. The neonate is the age at which the predisposition to hyperammonemia is more common, and approximately half of the cases give evidence in the neonatal period. Serious neurological sequelae, seizures, severe psychomotor retardation are seen in the survivors of hyperammonic decompensation (1-3). Despite early diagnosis and treatment, there is no good clinical course in the neonatal severe hyperammonemia, but the prognosis could be affected positively. Therefore, immediate diagnosis and treatment is important.

In this article, four cases of citrulinemia Type I, two cases of argininosuccinic aciduria that were diagnosed and started to receive treatment during the neonatal period as

\section{Address for Correspondence/Yazıșma Adresi}

Kıymet Çelik MD, Dr. Behçet Uz Children Disease and Surgery Training and Research Hospital, Clinic of Neonatology, Izmir, Turkey

Phone: +90 2324116000 E-mail:kymt_celik@yahoo.com.tr

Received/Geliş tarihi: 03.07.2016 Accepted/Kabul tarihi: 12.10.2016

${ }^{\circ}$ Copyright 2017 by Ege University and Ege Children's Foundation

The Journal of Pediatric Research, published by Galenos Yayınevi. 
well as the signs, diagnosis and treatment responses have been presented.

\section{Case Report}

Data were obtained by retrospectively examining the files of six patients who were diagnosed as UCD in the neonatal intensive care unit between 2010 and 2014. The gestational weeks of the cases ranged from 36 to 41 weeks, and birth weights ranged from 1990 to 4200 g. Three were girls, three boys. There was consanguinity between the parents of five patients. The demographic data of the cases are given in Table I. The application to hospital took place between the $3^{\text {rd }}$ and $19^{\text {th }}$ days of the postnatal period. They came with nonspecific and similar complaints like nourishment problems, vomiting, sleepiness. Intrusive breathing was remarkable among the complaints. A physical examination of all cases revealed dehydrated appearance, hypotonia and a decrease in newborn reflexes. Due to possibility of sepsis, ampiric antibiotherapy was started after taking blood culture. Blood gas and ammonia levels were studied with a preliminary diagnosis of metabolic disease in the cases in which infectious markers were negative. Respiratory alkalosis was present in the blood gases of all patients, and initial ammonia levels were determined to be between 689 and $1575 \mu \mathrm{g} / \mathrm{dL}$ (N: 68-136 $\mu \mathrm{g} / \mathrm{dL})$. When the results of the metabolic screenings that were sent with the pre-diagnosis of metabolic disease were evaluated, two patients with high argininosuccinic acid (ASA) levels in the plasma and urine were diagnosed with argininosuccinic aciduria, and four patients with no evidence of ASA and anhydrides in the blood and urine, but high serum citrulline levels both in the blood and urine were evaluated as citrullinemia Type I (Table II). Enzyme analysis and genetic tests could not be done.

High-calorie total parenteral nutrition was initiated by stopping protein intake for the cases of hyperammonemia. Oral sodium benzoate was applied at $250-500 \mathrm{mg} / \mathrm{kg} /$ day with intervals of six hours. Sodium phenyl acetate $(250 \mathrm{mg} /$ $\mathrm{kg})$ and sodium benzoate $(250 \mathrm{mg} / \mathrm{kg})$ were administered intravenously for 90 to 120 minutes after the initial (loading) doses of 250 to $500 \mathrm{mg} / \mathrm{kg} /$ day. Carbamoyl glutamate (carglumic acid) was administered by enteral route at a dose of $25 \mathrm{mg} / \mathrm{kg}$ for six hours after the $100 \mathrm{mg} / \mathrm{kg}$ loading. The treatment of patients with no decrease in the control ammonia levels was regulated with oral and intravenous sodium benzoate at $750 \mathrm{mg} / \mathrm{kg} /$ day. In the follow-up, it was observed that the ammonia level increased rapidly except for one case, and that one case was observed at the same level. Due to the fact that the control ammonia level did not decrease six hours after the ammonia-removing medical treatment agents (Table III), peritoneal dialysis (PD) was initiated with a PD catheter because of the lack of response of the patients to medical treatment, and the fact that hemodiafiltration is not available in our unit.

Phenobarbital therapy was started because of convulsions in the follow-up of five cases. Electroencephalography (EEG) could not be performed in two cases due to the infusion of midazolam and loss of the patient in early period. EEG was pathologic in two cases, in one case generalized burst suppression pattern, and in the other mild epileptiform disorder originating from the centrotemporal regions of both hemispheres was detected. In one case without convulsion, a sharp wave appearance was observed in the EEG in the right parieto-occipital region due to convulsions following discharge, and phenobarbital treatment was started. Cranial ultrasonography of the cases revealed no pathology. Eyeground examinations were usually normal. Cranial magnetic resonance (MR) and MR spectroscopy (MRS) could be applied to one patient. A myelination defect in both cerebral hemispheres was detected in the MR, while a peak of macromolecules was found to the right of the $\mathrm{N}$-acetylaspartate (NAA) picin in the MRS.

Except for one patient that was admitted on postnatal day 19 , five patients required mechanical ventilation support during the first day of admission, showing respiratory disturbance. Decrease in ammonia levels due to PD were detected (Table III). The ammonia level of the three patients decreased to the normal range $(<200 \mu \mathrm{g} / \mathrm{dL})$ between the $1^{\text {st }}$ and $4^{\text {th }}$ days of the PD treatment, and the patients were given oral sodium benzoate. However, a patient with metabolic balance was lost due to sepsis on postnatal day 41. In the other three cases, ammonia levels decreased in the first hours of PD, but patients lost follow-up because PD could not be continued due to catheter dysfunction (Table III).

\begin{tabular}{|l|l|l|l|l|l|l|}
\hline \multicolumn{6}{|l|}{ Table I. Demographic data of cases } \\
\hline Case no & Gestation week & Birth weight (grams) & Gender & Consanguineous marriage & Admission day & Admission symptom \\
\hline 1 & 38 & 4100 & Female & $(+)$ & $3^{\text {rd }}$ day & Nourishment problems \\
\hline 2 & 41 & 4200 & Male & $(+)$ & $3^{\text {rd }}$ day & Vomiting \\
\hline 3 & $36+2 / 7$ & 1990 & Female & $(+)$ & $19^{\text {th }}$ day & Nourishment problems \\
\hline 4 & 38 & 3600 & Female & $(+)$ & $3^{\text {rd }}$ day & Intrusive breathing \\
\hline 5 & 38 & 3500 & Male & $(+)$ & $4^{\text {th }}$ day & Intrusive breathing \\
\hline 6 & 39 & 3750 & Male & $(-)$ & $4^{\text {th }}$ day & Intrusive breathing \\
\hline
\end{tabular}




\section{Discussion}

The UCD mostly has an early onset (<28 days) (except for OTC deficiency), and high mortality especially in the neonatal period (4). Delay may occur due to the imitation of neonatal sepsis during the newborn period. Early diagnosis and urgent treatment are important in terms of prognosis and the influence of the accumulation of toxic metabolites. Continuous veno-venous hemodialysis or PD should be initiated urgently in patients unresponsive to dietary and pharmacological treatment, and continuing ammonio levels above $500 \mu \mathrm{mol} / \mathrm{L}$ (5). Because of the hemodynamic

\begin{tabular}{|c|c|c|c|c|c|c|}
\hline Case & Blood gas & $\begin{array}{l}\text { Ammonia } \\
(\mu \mathrm{g} / \mathrm{dL})\end{array}$ & Blood amino acids & $\begin{array}{l}\text { Urine amino } \\
\text { acids }\end{array}$ & Urinary orotic acid & Diagnosis \\
\hline 1 & $\begin{array}{l}\text { Respiratory } \\
\text { alkalosis }\end{array}$ & 1126 & $\begin{array}{l}\text { Glutamine, alanine, citrulline high, ASA } \\
\text { very high, } \\
\text { Arginine low }\end{array}$ & ${ }^{*}$ ASA high & High & $\begin{array}{l}{ }^{* *} \mathrm{ASL} \text { deficiency } \\
\text { Argininosuccinic aciduria }\end{array}$ \\
\hline 2 & $\begin{array}{l}\text { Respiratory } \\
\text { alkalosis }\end{array}$ & 1575 & $\begin{array}{l}\text { Glutamine, alanine, citrulline high, ASA } \\
\text { very high, } \\
\text { Arginine very low }\end{array}$ & ${ }^{*}$ ASA high & Could not performed & $\begin{array}{l}{ }^{* *} \mathrm{ASL} \text { deficiency } \\
\text { Argininosuccinic aciduria }\end{array}$ \\
\hline 3 & $\begin{array}{l}\text { Respiratory } \\
\text { alkalosis }\end{array}$ & 748 & $\begin{array}{l}\text { Glutamine, alanine moderately high, } \\
\text { Citrulline very high, } \\
\text { Arginine and ornithine low }\end{array}$ & Citrulline high & Could not performed & $\begin{array}{l}{ }^{* *} \text { ASS deficiency } \\
\text { Citrullinemia Type I }\end{array}$ \\
\hline 4 & $\begin{array}{l}\text { Respiratory } \\
\text { alkalosis }\end{array}$ & 1133 & $\begin{array}{l}\text { Glutamine, alanine high, } \\
\text { Citrulline very high, } \\
\text { Arginine and ornithine moderately low }\end{array}$ & Citrulline high & High & $\begin{array}{l}\text { ***ASS deficiency } \\
\text { Citrullinemia Type I }\end{array}$ \\
\hline 5 & $\begin{array}{l}\text { Respiratory } \\
\text { alkalosis }\end{array}$ & 689 & $\begin{array}{l}\text { Glutamine, alanine moderately high, } \\
\text { Citrulline very high, } \\
\text { Arginine and ornithine low }\end{array}$ & Citrulline high & High & $\begin{array}{l}{ }^{* *} \text { ASS deficiency } \\
\text { Citrullinemia Type I }\end{array}$ \\
\hline 6 & $\begin{array}{l}\text { Respiratory } \\
\text { alkalosis }\end{array}$ & 975 & $\begin{array}{l}\text { Glutamine, alanine high, } \\
\text { Citrulline very high, } \\
\text { Arginine and ornithine low }\end{array}$ & Citrulline high & High & $\begin{array}{l}{ }^{* *} \text { ASS deficiency } \\
\text { Citrullinemia Type I }\end{array}$ \\
\hline \multicolumn{7}{|c|}{$\begin{array}{l}\text { *ASA: Argininosuccinic acid } \\
\text { **ASL: Argininosuccinate lyase } \\
\text { ***ASS: Argininosuccinate synthetase }\end{array}$} \\
\hline
\end{tabular}

Table III. Treatment findings and prognosis

\begin{tabular}{|c|c|c|c|c|c|c|}
\hline Case no/diagnosis & 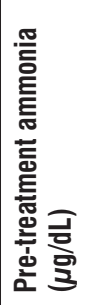 & 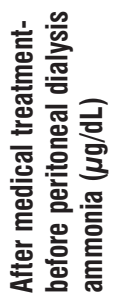 & 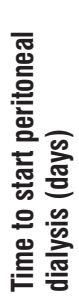 & 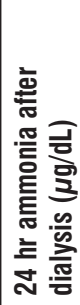 & 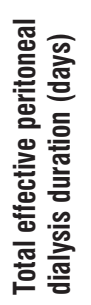 & 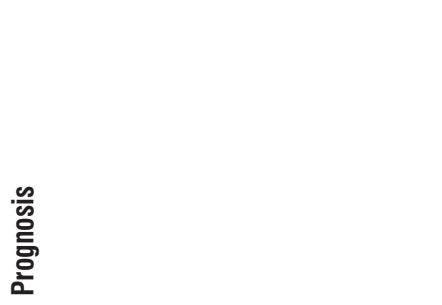 \\
\hline 1 Argininosuccinic aciduria & 1126 & 1981 & 3 & 713 & 4 & Postnatal exitus due to sepsis at 41 days \\
\hline 2 Argininosuccinic aciduria & 1575 & 1810 & 3 & 384 & 3 & Postnatal exitus on day 8 \\
\hline 3 Citrullinemia Type I & 748 & 744 & 19 & 73 & 1 & Follow-up case \\
\hline 4 Citrullinemia Type I & 1133 & 2359 & 3 & 1363 & 2 & Postnatal exitus on day 6 \\
\hline 5 Citrullinemia Type I & 689 & 1004 & 4 & 702 & 2 & Postnatal exitus on day 8 \\
\hline 6 Citrullinemia Type I & 975 & 1387 & 4 & 167 & 4 & Follow-up case \\
\hline
\end{tabular}


and technical complication frequency during the neonatal period, continuous veno-venous hemodiafiltration is recommended instead of hemodialysis. Continuous venovenous hemodialysis has been shown to be more effective and safer in the removal of toxic metabolites; the duration of dialysis is shorter, and the neurological outcomes are more favorable compared to those of PD (6). PD should be applied as an alternative method to cases where hemodiafiltration is not an option. Although hemodialysis has been considered more effective, some studies have shown that PD is still an effective treatment for hyperammonemic patients $(4,5)$. In our study, PD seemed to be effective when the level of ammonia decreased. PD can be effectively used in the neonatal period with the different indications besides metabolic diseases (7). Due to invasive interventions during PD, many complications like catheter leakage, catheter dysfunction, peritonitis, intestinal perforation can be observed. In our three cases, due to catheter dysfunction, PD can not be continued.

For UCD cases, since the maternal urea cycle metabolizes waste nitrogen that comes from the fetus, there are no complaints or signs during pregnancy and the first few days after birth. Hyperammonemic encephalopathy, which develops following this period of several days of well being, causes neurological findings. As ammonia levels increase; lethargy, vomiting, nourishment problems, hyperventilation, and intrusive breathing occur $(2,3,8)$. Cerebral edema due to hyperammonia causes hyperventilation and respiratory alkalosis (6,8). In our cases, respiratory alkalosis was accompanied by hyperammonia. The prognosis is directly related to the duration of hyperammonemic encephalopathy, the level of ammonia, the type of metabolic disease causing hyperammonia (9). For this reason, treatment should be started in the early period, and the patient transferred without delay to centres specializing in this field.

Blood gas, blood sugar, plasma acyl carnitine profile, blood lactate level, plasma and urine amino acids, urine organic acids, urine ketone and urinary orotic acid levels should initially be tested in cases of high ammonia level for the diagnosis of UCD. In addition, enzyme analysis and molecular genetic tests should be performed. Plasma citrulline level in UCD is helpful in locating the disorder. There is a significant increase in plasma citrulline levels in ASS deficiency (citrulline Type I). In the absence of ASL (argininosuccinic aciduria), plasma citrulline levels increase moderately $(5,8)$. If the plasma citrulline level is at or below trace level, CPS1 and OTC deficiency should be considered. In four of our cases, plasma citrulline levels were found to be very high, with moderate increase in two cases.

Neurological imaging findings in UCD are also associated with the duration of hyperammonemia as well as the level of ammonia. During the acute phase, cranial computed tomography and MR shows cerebral edema, whereas prolonged hyperammonemia shows similar findings to those of hypoxic ischemic encephalopathy. Cortical atrophy, cystic changes in white matter and hypomyelination are detected due to prolonged hyperammonia in OTC deficiency. In UCD, glutamate and glutamine are increased in MRS, and myosinolite is decreased. In addition, a decrease in NAA, cholinergic and creatinine may be detected $(8,10)$. In the MRS in our study a peak of macromolecules was found to the right of the NAA peak, while cranial MR, which could be applied to only one of our patients, showed myelinational defects in both cerebral regions.

During the neonatal period mortality was found to be $50 \%$ in severe cases (4). Similar mortality rates in our patients suggest that early initiation of PD may be an alternative treatment in centers where other treatment options are not available.

UCD should be kept in mind in our country, where consanguineous marriages are frequently encountered, in cases normal at birth but showing rapid progressive clinical deterioration, accompanied by convulsions and neurological findings, especially respiratory alkalosis in blood gas. In cases of severe hyperammonemia, early diagnosis and appropriate treatment should reduce mortality. However, since both mortality and severe neurological problems in living cases would increase morbidity, the ammonia should be removed rapidly.

\section{Ethics}

Informed Consent: Consent form was filled out by all participants.

Peer-review: External and internal peer-reviewed.

\section{Authorship Contributions}

Surgical and Medical Practices: K.Ç., S..K.G., M.K., Concept: K.Ç., Ö.O., Design: D.T., S.A., Data Collection or Processing: K.Ç., D.T., Analysis or Interpretation: E.S., S..Ç., S.A., Literature Search: K.Ç., Ö.O., Writing: K.Ç., D.T.

Conflict of Interest: No conflict of interest was declared by the authors.

Financial Disclosure: The authors declared that this study received no financial support.

\section{References}

1. Burgard P, Kölker S, Haege G, Lindner M, Hoffmann GF. Neonatal mortality and outcome at the end of the first year of life in early onset urea cycle disorders-review and metaanalysis of observational studies published over more than 35 years. J Inherit Metab Dis 2016;39:219-29.

2. Rezvani I, Yudkoff M. Urea cycle and hyperammonemia. In: Behman RE, Kliegman RM, Jenson HB (eds). Nelson Tetbook of Pediatrics, 19th ed. Saunders, Philadelphia, 2011;447-53.

3. Demirkol M. Üre döngüsü-Aminoasit metabolizması bozuklukları Içinde: Neyzi O, Ertuğrul T (eds). Pediatri, 4.baskı. Istanbul, Nobel Tıp Kitabevi, 2010;804-81. 
4. Waisbren SE, Gropman AL; Members of the Urea Cycle Disorders Consortium (UCDC), Batshaw ML. Improving long term outcomes in urea cycle disorders-report from the Urea Cycle Disorders Consortium. J Inherit Metab Dis 2016;39:573-84.

5. Häberle J. Role of carglumic acid in the treatment of acute hyperammonemia due to $\mathrm{N}$-acetylglutamate synthase deficiency. Ther Clin Risk Manag 2011;7:327-32.

6. Bilgin L, Unal S, Gunduz M, Uncu N, Tiryaki T. Utility of peritoneal dialysis in neonates affected by inborn errors of metabolism. J Paediatr Child Health 2014;50:531-5.

7. Ustyol L, Peker E, Demir N, Agengin K, Tuncer O. The Use of
Acute Peritoneal Dialysis in Critically III Newborns. Med Sci Monit 2016;22:1421-6.

8. Coşkun T, Hiperamonemi. İçinde: Coşkun T, Yurdakök M (eds). Yenidoğanda kalıtsal metabolik bozukluklar, 1. Baskı, Güneş tıp kitapevleri, 2014;67-82.

9. Pela I, Seracini D, Donati MA, Lavoratti G, Pasquini E, Materassi M. Peritoneal dialysis in neonates with inborn errors of metabolism: is it really out of date? Pediatr Nephrol 2008;23:163-8.

10. Häberle J, Boddaert N, Burlina A, et al. Suggested guidelines for the diagnosis and management of urea cycle disorders. Orphanet J Rare Dis 2012;7:32. 